\title{
Carbon-Neutrality in Wastewater Treatment Plants: Advanced Technologies for Efficient Operation and Energy/ Resource Recovery
}

\author{
Sungjun Bae ${ }^{1(1)}$ and Young Mo Kim ${ }^{2, *}$ \\ 1 Department of Civil and Environmental Engineering, Konkuk University, 120 Neungdong-ro, Gwangjin-gu, \\ Seoul 05029, Korea; bsj1003@konkuk.ac.kr \\ 2 Department of Civil and Environmental Engineering, Hanyang University, Seoul 04763, Korea \\ * Correspondence: youngmo@hanyang.ac.kr
}

check for

updates

Citation: Bae, S.; Kim, Y.M. Carbon-Neutrality in Wastewater Treatment Plants: Advanced Technologies for Efficient Operation and Energy/Resource Recovery. Energies 2021, 14, 8514. https:// doi.org/10.3390/en14248514

Received: 25 November 2021 Accepted: 15 December 2021 Published: 17 December 2021

Publisher's Note: MDPI stays neutral with regard to jurisdictional claims in published maps and institutional affiliations.

Copyright: (c) 2021 by the authors. Licensee MDPI, Basel, Switzerland. This article is an open access article distributed under the terms and conditions of the Creative Commons Attribution (CC BY) license (https:/ / creativecommons.org/licenses/by/ $4.0 /)$.

\section{Introduction}

Recently, "carbon neutrality", the state of net-zero carbon dioxide emission, has been one of the most frequently used terms in the sustainable development of environmental and energy industries. Indeed, many efforts have been made to advance novel technologies for resource recovery, material synthesis, and energy saving from various municipal and industrial wastes [1-9]. In particular, the development of energy-efficient water technologies and resource recovery from wastewater has become a non-trivial problem as (i) almost $4 \%$ of the global non- $\mathrm{CO}_{2}$ greenhouse gases (GHGs) are emitted from wastewater treatment plants (WWTPs) [10] and (ii) wastewater contains various organic/inorganic resources and even heat energy [11]. Therefore, many efforts have been put into improving energy self-sufficiency in sustainable WWTPs and developing sustainable processes for the recovery of many useful resources from WWTPs such as chemicals, nutrients, energy, and even water itself.

In the aspect of theoretical studies, Borzooei et al., suggested that the introduction of an advanced thickening stage and sludge pre-treatment can positively influence the energysaving and GHGs emission from WWTPs [12]. Hao et al. investigated the environmental impact of resource recovery from WWPTs by life cycle assessment (LCA), which concluded that (i) water reuse via effluent recycling is not sufficient for net-zero impact, and (ii) thermal energy recovery can play a significant role on environmental impact while phosphorus recovery limited the contribution [13]. Another LCA study concluded that (i) ozonation has the lowest life cycle costs compared to other options such as photo-Fenton and granular activated carbon and (ii) pyrolysis has the best profit compared to those of anaerobic digestion, wet air oxidation, and composting [14].

In the aspect of experimental studies, a pyrolysis product, known as biochar, from various organic wastes in agricultural activities and sludge of WWTPs, has been also considered as a promising up-cycled material for the treatment of wastewater. In particular, the efficient removal of organic and heavy-metal contaminants $[15,16]$ can reduce the GHGs emission from agricultural and environmental industries and produce clean water economically. Microbial fuel cells (MFCs) have also been extensively studied in the field of wastewater treatment as they can reduce the sludge disposal cost (accounting for almost $50 \%$ cost of WWTPs) [17]. Moreover, the additional possibility not only for the production of bioelectricity, but also the recovery of high-value products such as hydrogen $\left(\mathrm{H}_{2}\right)$, methane $\left(\mathrm{CH}_{4}\right)$, and hydrogen peroxide $\left(\mathrm{H}_{2} \mathrm{O}_{2}\right)$, has brought more attention to the WWTPs related researchers [18].

As discussed above, the sustainable development of WWTPs has become a hot topic worldwide. Thus, this Special Issue aimed to collect the state-of-the-art for the advances in WWTPs fields. Indeed, the papers published in this Special Issue cover a broad range of important issues; biochar application for wastewater treatment [19-21], LCA and cost 
optimization studies of WWTPs [22-24], enhanced anaerobic digestion [25], MFC of swine wastewater [26,27], and removal of radioactive and pharmaceutical pollutants by chemical processes $[28,29]$. In the next section, we provide a brief review of the papers published, roughly classifying them according to the thematic areas mentioned above.

\section{Short Review of the Contributions in This Issue}

Many papers can be grouped under the broad heading of Science and Technology.

The first topic is the recycling of carbon wastes for wastewater treatment. Many novel biochars were introduced in this Special Issue for the wastewater treatment contaminated by various aqueous pollutants. Kim et al. synthesized magnetic biochar from steel slag waste and pine sawdust (MSSB) for efficient $\mathrm{NH}_{4}-\mathrm{N}$ removal in an aqueous phase. They found that $\mathrm{NH}_{4}-\mathrm{N}$ was adsorbed on the MSSB surface via co-precipitation of $\mathrm{Mg}\left(\mathrm{NH}_{4}\right) \mathrm{PO}_{4}$ from magnesium and phosphate in biochar suspension [21]. The experimental results showed that the adsorption capacities of $\mathrm{NH}_{4}-\mathrm{N}$ can be influenced by many parameters such as $\mathrm{NH}_{4}-\mathrm{N}$ concentration, the ratio of steel slag to pine sawdust, and pyrolysis temperature. Another biochar was prepared by Lee et al. by using ground coffee residue with $\mathrm{NaOH}$ activation (GCRB-N). The BET area of GCRB-N was almost 100 times higher than that of GCRB without $\mathrm{NaOH}$ treatment [20], which resulted in the enhanced removal of three herbicides (i.e., Alachlor, Diuron, and Simazine) significantly. Zhao et al. succeeded the synthesis of optimized biochar derived from apple tree branches at different pyrolysis temperatures [19]. The optimized biochar prepared at $500^{\circ} \mathrm{C}$ showed the efficient sorption capacity toward aqueous $\mathrm{Cr}(\mathrm{II})$ and $\mathrm{Zn}(\mathrm{II})$, which was proceeded via surface precipitation, ion exchange, and cation-pi interaction.

The second topic is the optimization of energy saving and cost-effectiveness in WWTP. Szulc et al. showed the overall environmental impact of a WWTP in Poland by analyzing the LCA from the database in 2019 [22]. They concluded that energy components (e.g., WWTP process demand and electricity production) were the key factors to determine the sum of environmental impact. Karolinczak et al. investigated the cost analysis of the septage pre-treatment in subsurface vertical flow constructed wetland (SS-VF) prior to the municipal treatment plant [23]. The high cost-effectiveness of septage pre-treatment process in SS-VF (particularly in the rural area) compared to the conventional WWTP resulted from the low construction and operation costs coming from the reduction in the electricity consumption in biological section operation and lower cost of sludge management. Similarly, Gretzschel et al. concluded that implementing electrolysis operated with regenerative energy in combination with micropollutant removal using ozonation and activated carbon filter is a reasonable and sustainable option for climate and water protection [24]. Damtie et al. revealed that co-digestion of microalgae and primary sludge in thermophilic aerobic conditions can increase the methane yield up to $36 \%$, while the anaerobic pretreatment did not show any synergistic effect on the co-digestion process [25]. Therefore, the authors suggested the careful optimization of operating conditions during the production of methane from biological pretreatment of co-digestion.

The third topic is the MFC study. Ni et al. investigated the microbial community of anodic biofilm during the microbial fuel cells (MFCs) operation with swine wastewater [26,27]. They prepared three different modified anode carbon clothes and concluded that acid thermal modification can increase the power density up to 350\% rather than that without modification [26]. The modified anode also showed a significant impact on the microbial community, which was beneficial to improve the performance of MFCs in this study. Furthermore, they found that different concentrations of swine wastewater resulted in changes in the output voltage of MFC and COD removal rate, and microbial community diversity [27].

The last topic is the efficient chemical treatments for radioactive pollutant (i.e., cesium, Cs) and pharmaceutical contaminated wastewaters. Kim et al., demonstrated that the desorbed Cs from hydrobiotite could be treated by a sequential treatment method, i.e., pre-chemical precipitation (addition of $\mathrm{Ca}(\mathrm{OH})_{2}$ ) of non-radioactive cations and heavy 
metals, then post-Cs removal by sodium tetraphenylborate [29]. Lee et al. showed the enhanced oxidation of $17 \alpha$-ethinylestradiol, ibuprofen, and atenolol by microbubble ozonation process [28]. This was due to the higher specific area of ozone microbubbles than that of millibubbles, which could improve the mass transfer at the gas-water interface.

\section{Conclusions}

This Special Issue addresses the state-of-the-art findings in the field of WWTPs for sustainable development of WWTPs and implementation of carbon-neutrality. In particular, the contributions include the development of efficient and eco-friendly materials, assessment of cost and energy, energy-saving anaerobic digestion, and efficient chemical treatment. These papers can advance our fundamental knowledge of efficient management and operation of WWTPs and provide new insight to step forward for the accomplishment of carbon-neutrality of WWTPs in near future.

Author Contributions: S.B.; Y.M.K. The authors contributed equally to this work (Conceptualization, writing-review and editing). All authors have read and agreed to the published version of the manuscript.

Funding: This work was supported by the National Research Foundation of Korea (NRF) grant funded by the Korea government (MSIT) (No. 2021R1A2C2012451) and Korea Environment Industry \& Technology Institute (KEITI) through Ecological Imitation-based Environmental Pollution Management Technology Development Project, funded by Korea Ministry of Environment (MOE) (2021002800007).

Acknowledgments: We would like to give special thanks to the all authors who contributed the collection of scientific papers in this Special Issue.

Conflicts of Interest: The authors declare no conflict of interest.

\section{References}

1. Kim, M.; Bae, S. Immobilization and characterization of $\mathrm{Fe}(0)$ catalyst on $\mathrm{NaOH}$-treated coal fly ash for catalytic reduction of p-nitrophenol. Chemosphere 2018, 212, 1020-1029. [CrossRef] [PubMed]

2. Park, J.; Bae, S. Formation of Fe nanoparticles on water-washed coal fly ash for enhanced reduction of p-nitrophenol. Chemosphere 2018, 202, 733-741. [CrossRef]

3. Yoon, S.; Bae, S. Development of magnetically separable Cu catalyst supported by pre-treated steel slag. Korean J. Chem. Eng. 2019, 36, 1814-1825. [CrossRef]

4. Yoon, S.; Bae, S. Novel synthesis of nanoscale zerovalent iron from coal fly ash and its application in oxidative degradation of methyl orange by Fenton reaction. J. Hazard. Mater. 2019, 365, 751-758. [CrossRef]

5. Choi, M.; Park, J.; Yoon, S.; Lee, Y.K.; Hur, J.; Choe, J.K.; Nam, T.; Jung, S.P.; Bae, S. Enhanced denitrification of contaminated groundwater by novel bimetallic catalysts supported on kaolin-derived zeolite: Effects of natural dissolved inorganic and organic matter. Environ. Sci. Nano 2020, 7, 3965-3978. [CrossRef]

6. Park, J.; Choe, J.K.; Lee, W.; Bae, S. Highly fast and selective removal of nitrate in groundwater by bimetallic catalysts supported by fly ash-derived zeolite Na-X. Environ. Sci. Nano 2020, 7, 3360-3371. [CrossRef]

7. Kim, J.; Coulibaly, G.N.; Yoon, S.; Assadi, A.A.; Hanna, K.; Bae, S. Red mud-activated peroxymonosulfate process for the removal of fluoroquinolones in hospital wastewater. Water Res. 2020, 184, 116171. [CrossRef]

8. Yoon, S.; Choi, M.; Hwang, Y.; Bae, S. Upcycling of steel slag for manufacture of Prussian-blue-encapsulated pectin beads and its use for efficient removal of aqueous cesium. J. Clean. Prod. 2021, 319, 128786. [CrossRef]

9. Park, S.; Kim, M.; Lim, Y.; Yu, J.; Chen, S.; Woo, S.W.; Yoon, S.; Bae, S.; Kim, H.S. Characterization of rare earth elements present in coal ash by sequential extraction. J. Hazard. Mater. 2021, 402, 123760. [CrossRef]

10. United States Environmental Protection Agency. Global Anthropogenic Non-CO $\mathrm{CO}_{2}$ Greenhouse Gas Emissions: 1990-2030; United States Environmental Protection Agency: Washington, DC, USA, 2012.

11. Hao, X.; Li, J.; van Loosdrecht, M.C.M.; Jiang, H.; Liu, R. Energy recovery from wastewater: Heat over organics. Water Res. 2019, 161, 74-77. [CrossRef]

12. Borzooei, S.; Campo, G.; Cerutti, A.; Meucci, L.; Panepinto, D.; Ravina, M.; Riggio, V.; Ruffino, B.; Scibilia, G.; Zanetti, M. Optimization of the wastewater treatment plant: From energy saving to environmental impact mitigation. Sci. Total Environ. 2019, 691, 1182-1189. [CrossRef] [PubMed]

13. Hao, X.; Wang, X.; Liu, R.; Li, S.; van Loosdrecht, M.C.M.; Jiang, H. Environmental impacts of resource recovery from wastewater treatment plants. Water Res. 2019, 160, 268-277. [CrossRef] 
14. Tarpani, R.R.Z.; Azapagic, A. Life cycle costs of advanced treatment techniques for wastewater reuse and resource recovery from sewage sludge. J. Clean. Prod. 2018, 204, 832-847. [CrossRef]

15. Shin, J.; Kwak, J.; Lee, Y.G.; Kim, S.; Choi, M.; Bae, S.; Lee, S.H.; Park, Y.; Chon, K. Competitive adsorption of pharmaceuticals in lake water and wastewater effluent by pristine and $\mathrm{NaOH}$-activated biochars from spent coffee wastes: Contribution of hydrophobic and $\pi-\pi$ interactions. Environ. Pollut. 2021, 270, 116244. [CrossRef] [PubMed]

16. Shin, J.; Bae, S.; Chon, K. Fenton oxidation of synthetic food dyes by Fe-embedded coffee biochar catalysts prepared at different pyrolysis temperatures: A mechanism study. Chem. Eng. J. 2021, 421, 129943. [CrossRef]

17. Ye, Y.; Ngo, H.H.; Guo, W.; Chang, S.W.; Nguyen, D.D.; Liu, Y.; Ni, B.J.; Zhang, X. Microbial fuel cell for nutrient recovery and electricity generation from municipal wastewater under different ammonium concentrations. Bioresour. Technol. 2019, $292,121992$. [CrossRef] [PubMed]

18. Munoz-Cupa, C.; Hu, Y.; Xu, C.; Bassi, A. An overview of microbial fuel cell usage in wastewater treatment, resource recovery and energy production. Sci. Total Environ. 2021, 754, 142429. [CrossRef] [PubMed]

19. Zhao, S.; Ta, N.; Wang, X. Absorption of $\mathrm{Cu}(\mathrm{II})$ and $\mathrm{Zn}(\mathrm{II})$ from aqueous solutions onto biochars derived from apple tree branches. Energies 2020, 13, 3498. [CrossRef]

20. Lee, Y.G.; Shin, J.; Kwak, J.; Kim, S.; Son, C.; Cho, K.H.; Chon, K. Effects of naoh activation on adsorptive removal of herbicides by biochars prepared from ground coffee residues. Energies 2021, 14, 1297. [CrossRef]

21. Kim, G.; Kim, Y.M.; Kim, S.M.; Cho, H.U.; Park, J.M. Magnetic steel slag biochar for ammonium nitrogen removal from aqueous solution. Energies 2021, 14, 2682. [CrossRef]

22. Szulc, P.; Kasprzak, J.; Dymaczewski, Z.; Kurczewski, P. Life Cycle Assessment of Municipal Wastewater Treatment Processes Regarding Energy Production from the Sludge Line. Energies 2021, 14, 356. [CrossRef]

23. Karolinczak, B.; Miłaszewski, R.; Dąbrowski, W. Cost optimization of wastewater and septage treatment process. Energies 2020 13, 6406. [CrossRef]

24. Gretzschel, O.; Schfer, M.; Steinmetz, H.; Pick, E.; Kanitz, K.; Krieger, S. Advanced wastewater treatment to eliminate organic micropollutants in wastewater treatment plants in combination with energy-efficient electrolysis at WWTP Mainz. Energies 2020, 13, 3599. [CrossRef]

25. Damtie, M.M.; Shin, J.; Jang, H.M.; Kim, Y.M. Synergistic Co-Digestion of Microalgae and Primary Sludge to Enhance Methane Yield from Temperature-Phased Anaerobic Digestion. Energies 2020, 13, 4547. [CrossRef]

26. Ni, H.; Wang, K.; Lv, S.; Wang, X.; Zhang, J.; Zhuo, L.; Li, F. Effects of Modified Anodes on the Performance and Microbial Community of Microbial Fuel Cells Using Swine Wastewater. Energies 2020, 13, 3980. [CrossRef]

27. Ni, H.; Wang, K.; Lv, S.; Wang, X.; Zhuo, L.; Zhang, J. Effects of concentration variations on the performance and microbial community in microbial fuel cell using swine wastewater. Energies 2020, 13, 2231. [CrossRef]

28. Lee, Y.G.; Park, Y.; Lee, G.; Kim, Y.; Chon, K. Enhanced degradation of pharmaceutical compounds by a microbubble ozonation process: Effects of temperature, $\mathrm{pH}$, and humic acids. Energies 2019, 12, 4373. [CrossRef]

29. Kim, S.M.; Yoon, I.H.; Kim, I.; Kim, J.H.; Park, S.J. Hydrothermal desorption of Cs with oxalic acid from hydrobiotite and wastewater treatment by chemical precipitation. Energies 2020, 13, 3284. [CrossRef] 